\title{
STHREEPURA CAVE AT KIRIWANAGAMA, SOUTH CENTRAL SRI LANKA: A NETWORK CAVE IN SAPROLITE AND PROTEROZOIC QUARTZITE
}

\author{
JAMA STHREEPURA PRI KIRIWANAGAMI, \\ JUŽNI DEL OSREDNJE ŠRI LANKE: MREŽA ROVOV \\ V SAPROLITU IN PROTEROZOJSKEM KVARCITU
}

Pathmakumara JAYASINGHA ${ }^{1,2}$, Robert Armstrong Lee OSBORNE ${ }^{2,3,4, \star}$ \& Ross E. POGSON ${ }^{4}$

\begin{abstract}
UDC 551.442:549.514.51(548.79)

Pathmakumara Jayasingha, Robert Armstrong Lee Osborne \& Ross E. Pogson: Sthreepura cave at Kiriwanagama, south central Sri Lanka: A network cave in saprolite and proterozoic quartzite

Sthreepura Cave at Kiriwanagama consists of an upper level of cavities in quartzite formed by arenization and a lower level developed in a saprolite formed from the weathering of gneiss sandwiched between two layers of quartzite. The lower level cave is not like most arenization and phantom rock caves as the walls are composed of saprolite, not exhumed unweathered rock. The cave is not a soil pipe as it is not in soil, lacks the characteristic features of soil pipes and has formed directly below, not above an aquiclude. Sthreepura Cave at Kiriwanagama is a network cave in saprolite. Speleogenesis in the lower level began with the development of joint-guided tubes in the saprolite directly below the upper layer of quartzite, probably under phreatic conditions. Later erosion under vadose conditions removed the saprolite to produce a network of passages with a rectangular profile. Widening of the passages ultimately caused ceiling failure producing breakdown chambers, but fallen slabs of quartzite armoured the walls of the Main Passage of the cave protecting them from undercutting.
\end{abstract}

Key words: Sri Lanka, gneiss, network cave, saprolite, arenization.

\author{
Izvleček \\ UDK 551.442:549.514.51(548.79) \\ Pathmakumara Jayasingha, Robert Armstrong Lee Osborne \& \\ Ross E. Pogson: Jama Sthreepura pri Kiriwanagami, južni del \\ osrednje Šri Lanke: Mreža rovov v saprolitu in proterozojskem \\ kvarcitu
}

Jamo St hreepura pri Kiriwanagami sestavljata gornji nivo arenizacijskih votlin $\mathrm{v}$ kvarcitu ter spodnji nivo v saprolitu, ki je nastal s preperevanjem gnajsa med plastmi kvarcita. Tudi stene rovov spodnjega nivoja so iz saprolita, kar kaže na drugačen razvoj od znanih arenizacijskih in fantomskih jam. Jama nima lastnosti preperinskih cevi in je $\mathrm{v}$ nasprotju s temi nastala neposredno pod (in ne nad) akvikludom.

Jama Sthreepura pri Kiriwanagami predstavlja mrežo kanalov nastalih v saprofitu.. Speleogeneza se je začela z razvojem cevi vzdolž razpok v saprolitu, neposredno pod gornjo plastjo kvarcita, verjetno $\mathrm{v}$ freatičnih pogojih. Kasnejša erozija v vadozni coni je saprolit odstranila in tako ustvarila mrežo rovov pravokotnega profila. Širjenje rovov je privedlo do rušenja stropa in nastanka podornih dvoran. V glavnem rovu so padli bloki kvarcita zaščitili stene in preprečili nadaljnje spodkopavanje $\mathrm{v}$ glavnem rovu jame.

Ključne beside: Šri Lanka, gnajs, mreža rovov, saprolit, arenizacija.

\footnotetext{
${ }^{1}$ National Building Research Organization, 99/1 Jawatta Rd, Colombo 05, Sri lanka, e-mail: jpathmak@gmail.com

${ }^{2}$ Lanka Institute of Cave Science, 1/66 Mayura Mawatha, Pepiliyana, Sri Lanka

3 The University of Sydney, Sydney School of Education and Social Work NSW, 2006, Australia,

e-mail: armstrong.osborne@sydney.edu.au

${ }^{4}$ Geosciences, Australian Museum, 1 William Street, Sydney, NSW, 2010, Australia, e-mail: rossp@austmus.gov.au

* Corresponding author
}

Received/Prejeto: 25.02 .2016 


\section{INTRODUCTION}

There has been considerable interest in cave forming processes that involve the alteration or weathering of the host rock in the shape of a cave, followed by the mechanical or solutional removal of the altered rock. These processes have several names, as does the altered material that is removed to form the cave. The term Arenization is used to describe the disintegration of quartz sandstone (Martini 1979; Wray \& Sauro 2017), or granite (Braga et al. 2002) into sand by the solution of cement or matrix. Vergari and Quinif (1997) introduced the term phantom rock, also called ghost rock to describe altered impure limestone, which was later removed to reveal a cave. Quinif (2011) and Dubois et al. (2014) expanded on this work. Häuselmann and Tognini (2005) used the term phantom cave to describe a cave in sandstone, formed by the removal of altered rock, which they found to have a "phantomic" genesis. Urban et al. (2007) also used the term phantom caves in a similar manner.

Geršl et al. (1999) however used the term phantom caves in a completely different sense to describe unroofed caves in the last stage of denudation when only a tiny trace of the cave remained. In a footnote, Šušteršič (2003) attempted to solve this problem by suggesting that unroofed caves in the last stage of denudation should be called ghost caves. This is still problematic due to the use of "ghost" as a synonym for "phantom", so while it may be reasonable to say in reference to an unroofed cave in the last stage of denudation that "only a ghost of a cave remains" it would seem to be unwise to apply the term ghost cave to an unroofed cave.

Aubrecht et al. (2011) introduced the term lateritization to describe an intense in-situ weathering process that resulted in the solution of feldspars and mica producing both cave voids and dissolved silica for speleothem formation.

Ghost rock, phantom rock and phantom cave processes have generally been used to explain the origin of caves in carbonate rock. In the parakarst realm the debate has been about the relative roles or lack of role of silica solution, arenization and lateritization in the formation of caves in silicate rocks.

This debate has focussed on the origin of caves on the Venezuelan tepuis, which are very different in scale and are developed in a very different bedrock and environment to the cave we describe below.

Aubrecht et al. (2011) attributed the origin of the sandstone caves on the Venezuelan tepuis to two principal processes; the removal of poorly lithified sandstone not arenization as had been previously proposed, and to a process they described as "lateritization" involving the deep weathering of arkosic sandstones and greywackes resulting in the production of "laterite". They described the red mud in the caves as having "a mineral composition of goethite, kaolinite, illite, quartz and pyrophyllite, i.e., it represents true laterite" (Aubrecht et al. 2011, p. 363). While Aubrecht et al. (2011) discussed at great length the arguments against speleogenesis by arenization and the definition of pseudokarst, they did not discuss their use of the terms laterite and "lateritization" or the way they have applied it to caves. Sauro et al. (2013) disagreed with Aubrecht et al. (2011), however Aubrecht et al. (2013) replied by restating that most of the cave formation was not due to arenization but to "the dissolution of quartz or by the dissolution of alminosilicates (lateritization)."

There is a large body of literature about laterite and lateritization, but much less about caves in laterite or laterite in caves. The idea that lateritization is primarily about quartz and aluminosilicate solution is however a minority view. The review of laterite by Retallack (2010) begins with the simple statement that "Laterites and bauxites are rocks enriched in iron and aluminium respectively" (Retallack 2010, p. 655). Caves formed by the removal of the pallid zone below a strong laterite crust have been described from India by Kale (2014), Serra Leone by Bowden (1980), Australia by Twidale (1987) and McFarlane and Twidale (1987). These caves with roofs composed of rocks enriched in iron must truly be lateritic caves.

Laterites sensu Retallack (2010), soils and weathering profiles with distinct iron-enriched zones and iron-poor pallid zones are common in Sri Lanka so it would be unwise to apply the term laterite to strongly-weathered materials that are not associated with iron enrichment. The cave we describe below is largely formed by the removal of an in-situ deeply weathered compositional layer (folium) in the gneiss without significant iron enrichment, so we have decided to call this weathered material a saprolite, a term used by Braga et al. (2002) to describe "in situ weathering products of granitoid rocks".

Osborne et al. (2013) described caves in Sri Lanka developed in granitic gneiss by a weathering and removal process that mimicked the phantom rock process described in limestone caves by Dubois et al., (2014). In these caves granitic gneiss was weathered into a friable material that was washed out to expose a cave wall composed of un-weathered gneiss. The cave we describe below differs from these types of caves in that the cave walls are not composed of un-weathered gneiss but saprolite. 


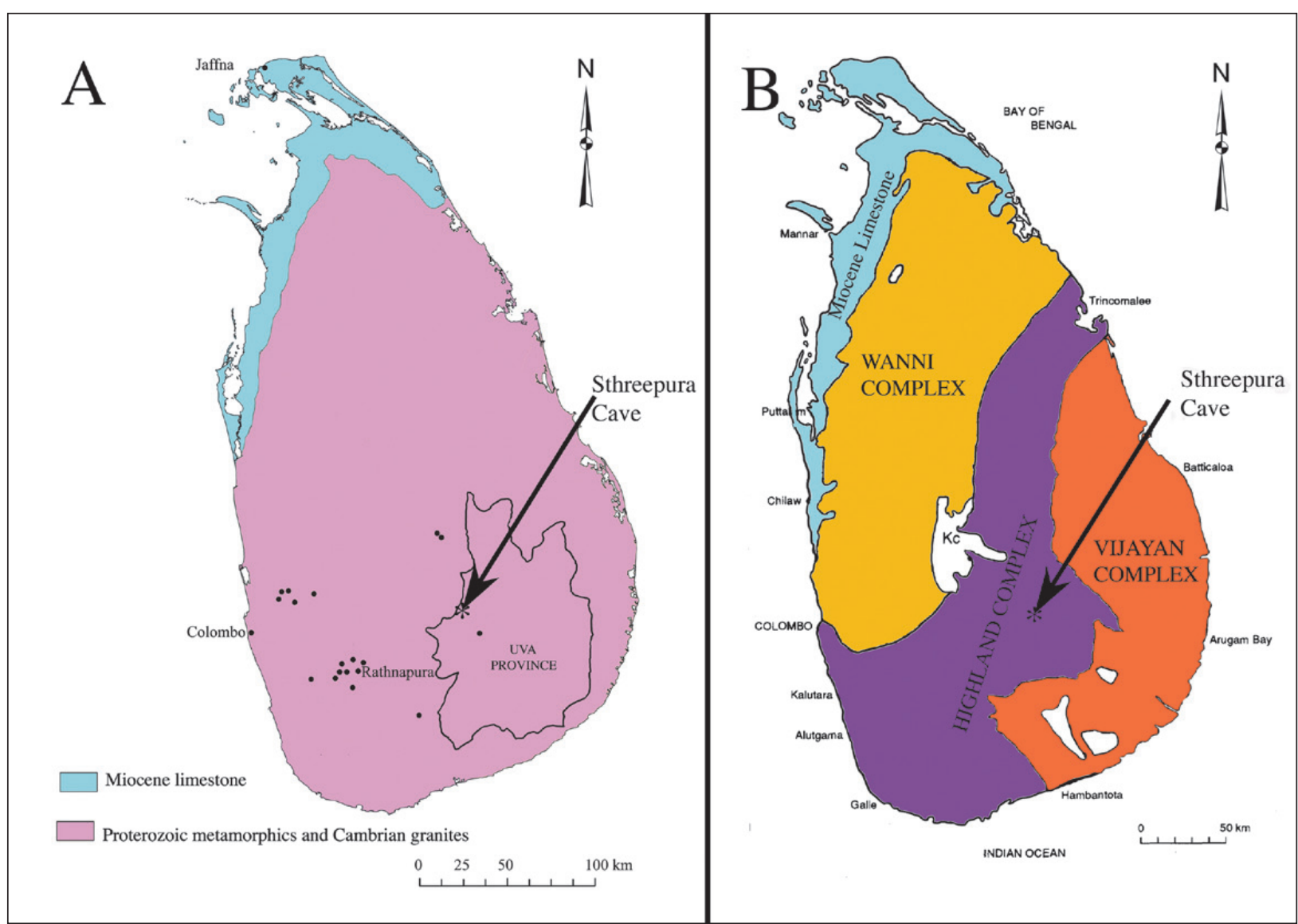

Fig. 1: $A=$ Gross lithology of Sri Lanka and location of Sthreepura Cave. B = Geological provinces after Cooray (1994). Kc= Kadugannawa Complex, biotite gneisses near Kandy.

\section{LOCATION}

Sri Lanka is a teardrop shaped island lying to the southeast of the Indian subcontinent. Most of the island and all of its highlands are composed of silicic Proterozoic gneiss containing a few bodies of marble, while the northern end of the island is composed of Miocene limestone (Fig. 1A). Osborne et al. (2013) described the range of cave types developed in Proterozoic gneiss in Sri Lanka and noted that phantom rock processes could be recognised at four localities.

Sthreepura Cave at Kiriwanagama is not to be confused with Sthreepura Cave at Batathota or the now flooded Sthreepura Cave at Pannala (Basnayake 1983). It is located $116 \mathrm{~km}$ east of Colombo in Uva Province in central southern Sri Lanka (Fig. 1A). Sthreepura, also spelt Isthripura, is derived from Sanskrit and Sinhalese sthri meaning woman and pura meaning town and refers to a mythical incident where King Walagamba hid 500 queens in a cave to protect them (Basnayake 1983).
Three cave entrances, one in a doline, occur at an elevation of approximately $1390 \mathrm{~m}$ a.s.l. on the northwestern face of a NE-SW trending cuesta ridge. The ridge crest has an elevation of $1424 \mathrm{~m}$ a.s.l. and slopes to the northwest at approximately 20 degrees. The hill slope steepens downhill from the cave and steepens again close to the stream at the base of the cuesta. After wet weather, a spring was located in the valley at the base of the cuesta face at an elevation of approximately $1358 \mathrm{~m}$ a.s.l. Shallow v-shaped valleys running south to north are incised into the face of the cuesta. There is little soil on the hill face, with much exposed bedrock. The dominant plants on the hill are large eucalyptus trees apparently planted to stabilize the slope after the original forest was cleared some thirty years ago. Two concrete fences running E-W, apparently intended to direct sheet-flow away from the cave entrances, have been constructed uphill of the Main and Blind Entrances (Fig. 2). 


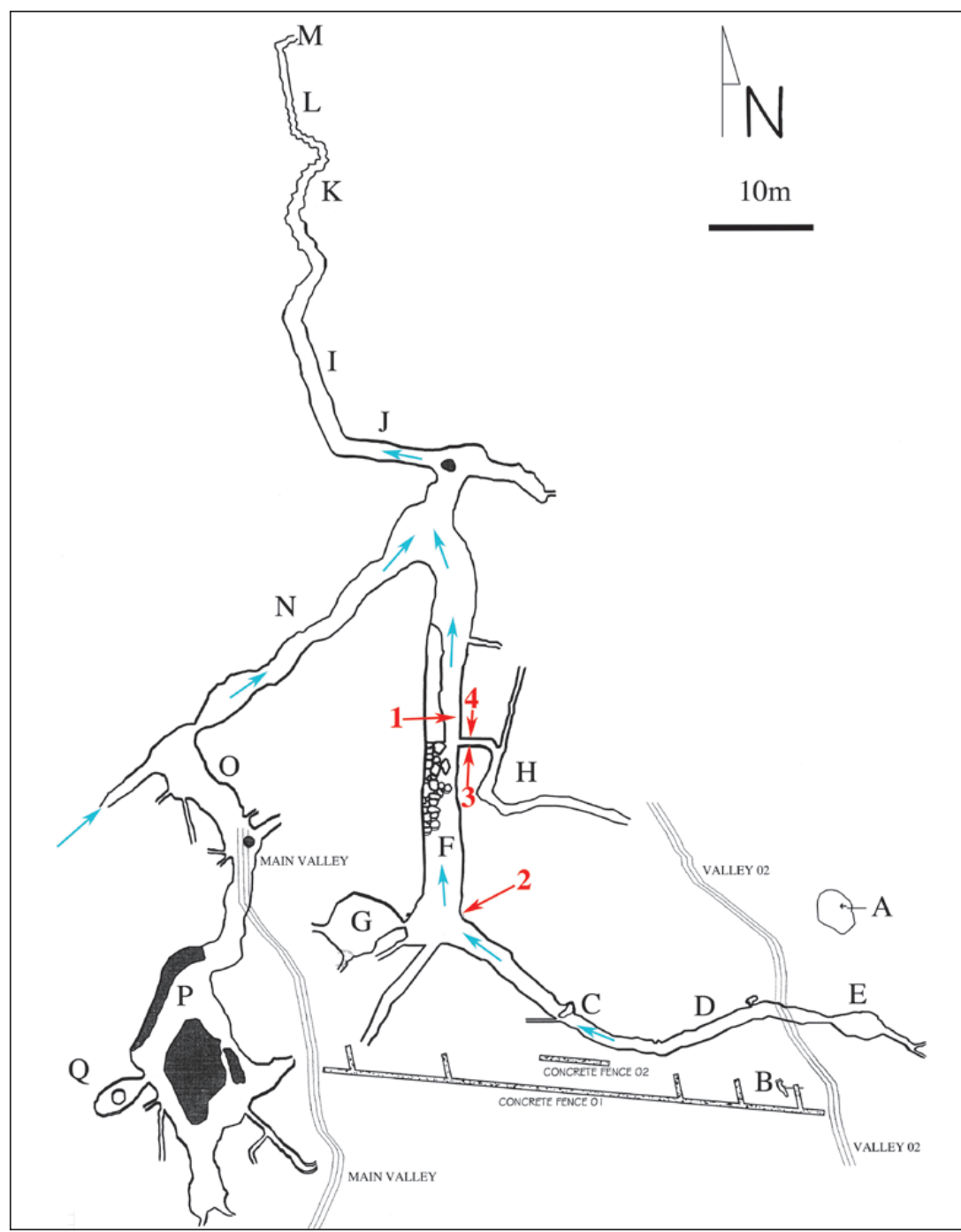

METHODS
Fig. 2: Cave map after Dandeniya et al. (2015). $A=$ Doline. $B=$ Blind Entrance. $C=$ Main Entrance. $D=$ East Passage. $E=$ East Breakdown Chamber. $F=$ Main Passage. $G=$ West Breakdown Chamber. $H=$ Eastern Maze. $I$ = Descending Passage. $J=E-W$ Section of Descending Passage. $K=$ Meandering canyon in Descending Passage. $L=$ Tube in Descending Passage wall. $M=$ Final Chamber. $N=$ Southwest Passage. $O=$ Rising Passage. $P=$ Island Room. $Q=$ Cupola. Blue arrows indicate water flow observed on $2^{\text {nd }}$ December, 2014.
The cave was investigated over 6 days between March 2012 and December 2014.

Surveys were made using a Suunto compass for direction and a Disto D8 for length and inclination. Structural data was measured using a stratum compass.

Wall soundings were taken using SDS rock bits in both a hand brace and a battery-powered hammer drill.

$\mathrm{X}$-ray diffraction (XRD) analysis was undertaken at the Australian Museum, Sydney, using Philips PW1730/ PW1050 and Panalytical X'Pert Pro equipment. A graphite monochromator and proportional counter were used, with $40-45 \mathrm{kV}$ and $30-40 \mathrm{~mA}$ of $\mathrm{Cu}-\mathrm{ka}$ radiation. Scans were run from $2^{0}$ to $70^{\circ} 2 \theta$ at 1.2 to $0.6^{\circ}$ /minute with $1^{0}$ divergence slit, $2^{0}$ antiscatter slit, $0.1 \mathrm{~mm}$ receiver slit and $0.02^{0}$ step size.

\section{GEOLOGY}

The geology of Sri Lanka is dominated by Proterozoic high-grade metamorphic rocks, which cover about $80 \%$ of the landmass (Cooray 1994). Sthreepura Cave is locat- ed in the oldest cratonic rock belt known as the Highland Complex (Fig. 1B). The rocks of this complex are highly folded and sheared while those in the other two belts, the 


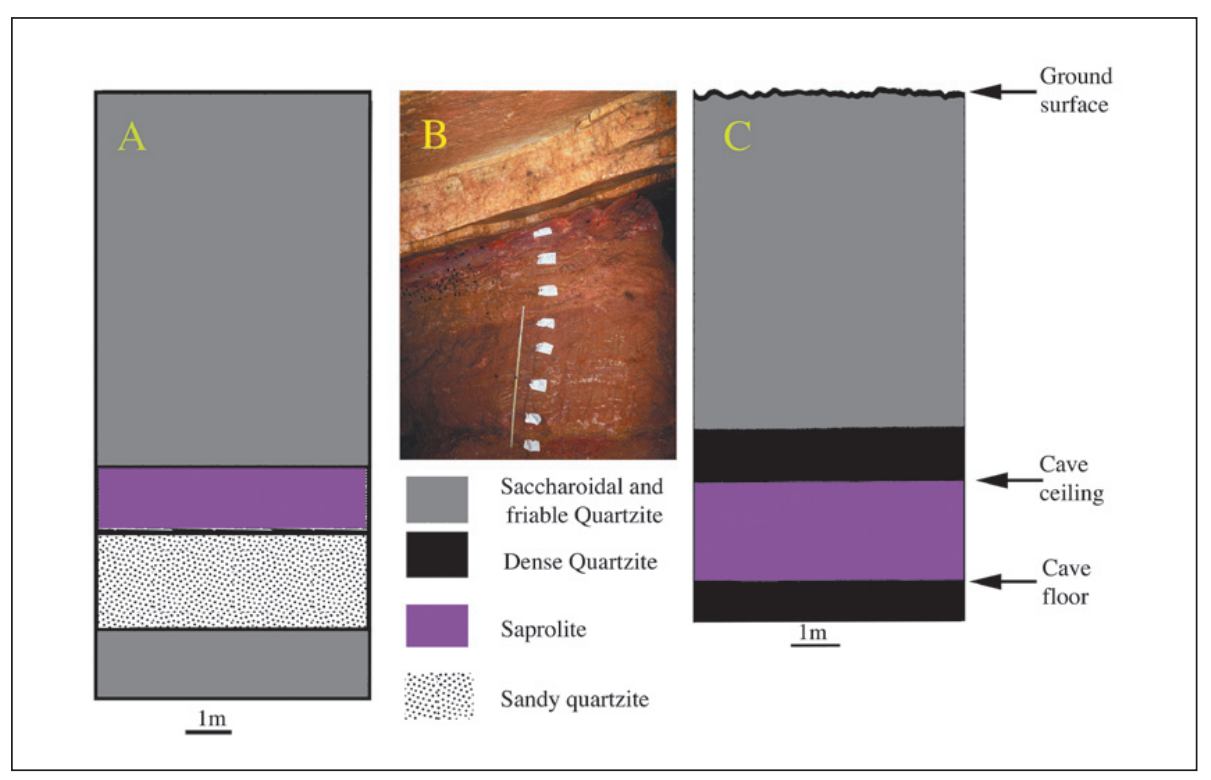

Fig. 3: $A=$ Section exposed at southern edge of ridge. $B=\mathrm{Sec}$ tion in cave wall at Red " 1 " in Fig. 2 showing ceiling quartzite, top and saprolite below, white rule is $1 \mathrm{~m}$ (Photo: P. Jayasingha). C = Composite section based on observations in Main Entrance shaft and cave walls.
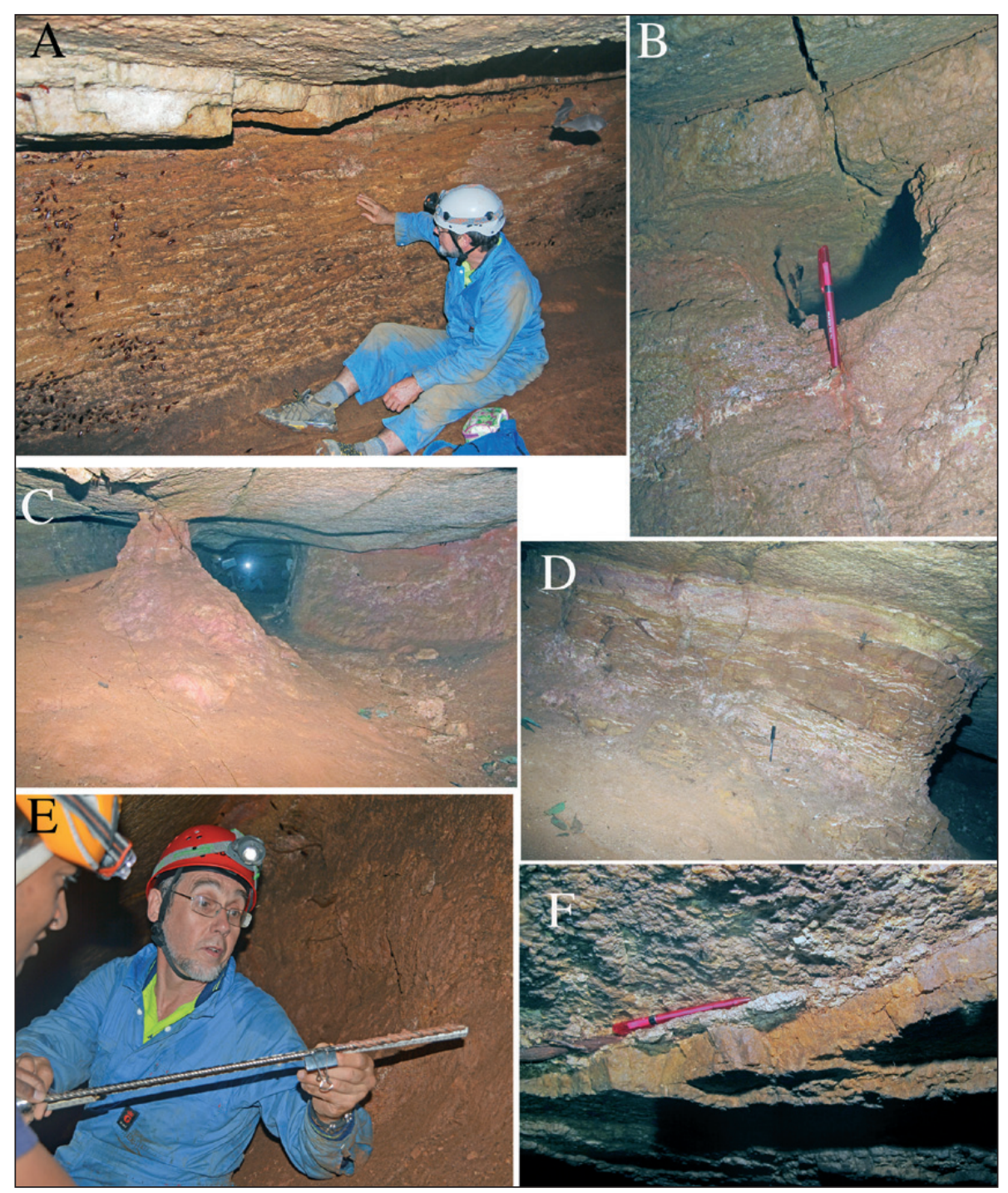

Fig. 4: $A=$ Saprolite in wall of Main Passage showing foliation (Photo: A. Weliange). $B=$ Tube in top of saprolite in eastern wall of Descending Passage near " $L$ " in Fig. 2. Note joint in overlying quartzite dips to the south and its' trace extends down into the saprolite. Pen is $140 \mathrm{~mm}$ long (Photo: R.A.L. Osborne). $C=$ Residual pillar of saprolite towards the northeastern side of the Rising Passage (Photo: R.A.L. Osborne). $D=$ Section through saprolite in side of the "island". Note well-developed traces of foliation. Pen for scale is 130 mm (Photo: R.A.L. Osborne). $E=$ Measuring penetration after drilling with hand brace at site "Red 2" in Fig. 2 (Photo: A. Weliange). $F=$ White paste close to ceiling of East Passage. Pen is $140 \mathrm{~mm}$ long. 
Wanni and Vijayan complexes, are much less deformed (Fig. 1B). Most of the rocks in the area near the cave are silicic metamorphics, such as garnet sillimanite gneiss, charnockitic gneiss, hornblende biotite gneiss, quartzofelspathic gneiss and quartzite.

Massive saccharoidal quartzite covered by little or no soil crops out to form the northwestern dipping cuesta face of the ridge. At the back (southern) edge of the ridge, $260 \mathrm{~m}$ south of the cave entrance, a sequence consisting of a basal quartzite, a folium of "sandy" coarse grained quartzite with what appear to be solution cavities, a folium of saprolite and an upper quartzite folium of saccharoidal and friable quartzite, is exposed (Fig. 3A).

The sequence exposed in the cave walls consists of a lower dense quartzite folium, the "floor quartzite" which is sometimes exposed as the cave floor, a folium of saprolite and an upper dense quartzite folium, the "ceiling quartzite" which in most places forms the cave ceiling (Fig. 3B, Red "1" in Fig. 2).

A composite section based on exposures in the Main Entrance shaft and the cave walls (Fig. 3C) shows a basal layer of dense massive quartzite forming the cave floor, $1.9 \mathrm{~m}$ of saprolite exposed in the cave walls, approximately $1 \mathrm{~m}$ of dense massive quartzite forming the cave ceiling and $6.7 \mathrm{~m}$ of saccharoidal and friable quartzite between the top of the "ceiling quartzite" and the ground surface. While the folia are largely planar, some folding is apparent such as the small anticline exposed in the Rising Passage.

The saprolite forming the cave walls has specific characteristics. Firstly, it retains traces of the foliation and textural and mineralogical variations of the original rock (Fig. 4A). Secondly, there is no sign in the cave that there is any change in the degree of weathering either vertically or horizontally across the saprolite folium. Where joints are exposed in the saprolite, as seen in Fig. 4B, there is no change in the degree of weathering adjacent to the joint and the joint in the saprolite remains tight, while joints in the overlying quartzite are open. Consistent with an overall even degree of weathering, no core-stones are exposed in the cave walls.

Initially, we thought that there might be unweathered or significantly less-weathered rock a short distance inside the cave walls. Careful observations of the saprolite pillar in the Rising Passage (Fig. 4C) and the "island" in the Island Room (Fig. 4D) gave no indication that saprolite deep inside the walls was significantly lessweathered than that exposed at the surface of the cave walls. In order to test the strength of saprolite in the cave walls, soundings were made with a $580 \mathrm{~mm}$ SDS drill in the eastern wall of the Main Passage at "Red 2" in Fig. 2, Fig. 4E, and into the wall of the Eastern Maze at "Red 3" and "Red 4" in Fig. 2. The soundings gave no indication that the saprolite significantly increased in strength with distance into the cave walls.

$\mathrm{X}$-ray diffraction of a sample of the saprolite from the cave wall in the East Passage indicated the presence of only two minerals, kaolinite-1A with well-developed peaks and hematite. No peaks for quartz, feldspar, biotite, garnet or other minerals commonly occurring in gneiss were identified.

Unlike the Sri Lankan caves in gneiss described by Osborne et al. (2013), no speleothems, neither silica nor carbonate, with the exception of one tiny silica stalagmite, have been found in Sthreepura Cave at Kiriwanagama. The only cave mineral so far identified in the cave is a small deposit of a white coloured pasty material sitting on a tree root adjacent to quartzite close to the ceiling of the East Passage (Fig. 4F). X-ray diffraction showed the presence of two main components: major kaolinite-1A and lesser illite-2M, both with sharp peaks and the possibility of some very minor quartz.

\section{SURFICIAL KARST-LIKE FEATURES}

The largest surface karst-like feature is an elliptical breakdown doline partly filled with unconsolidated sediment ("A" in Fig. 2, Fig. 5A). The doline has a $4.8 \mathrm{~m}$ long axis, striking $160^{\circ}$ and a $3.5 \mathrm{~m}$ long short axis, striking $070^{\circ}$. A $3 \mathrm{~m}$ scarp is developed on its uphill, southern side with a small $1.7 \mathrm{~m}$ step onto its floor on the downhill, northern side. The southern end of the doline appears to be a cave entrance blocked by sediment and bats fly in and out of the doline in the evening.

Uphill from the doline and to the east of the Main Entrance is a small vertical opening, the Blind Entrance ("B" in Fig. 2, Fig. 5B). The Blind Entrance connects to a small chamber developed in saccharoidal quartzite. Near the entrance, the chamber roof is $1.3 \mathrm{~m}$ thick. Joints dipping steeply to the south are visible in the ceiling to the right of frame in Fig. 5C while foliation dipping to the north is visible to the left. A hole in the base of the chamber penetrates through the "ceiling quartzite" and with further digging might connect to more open cave.

In December 2014, a spring was observed rising in the bed of the creek at the base of the cuesta slope $136 \mathrm{~m}$ to the northeast and at a level approximately 36 mbelow the cave entrance. 


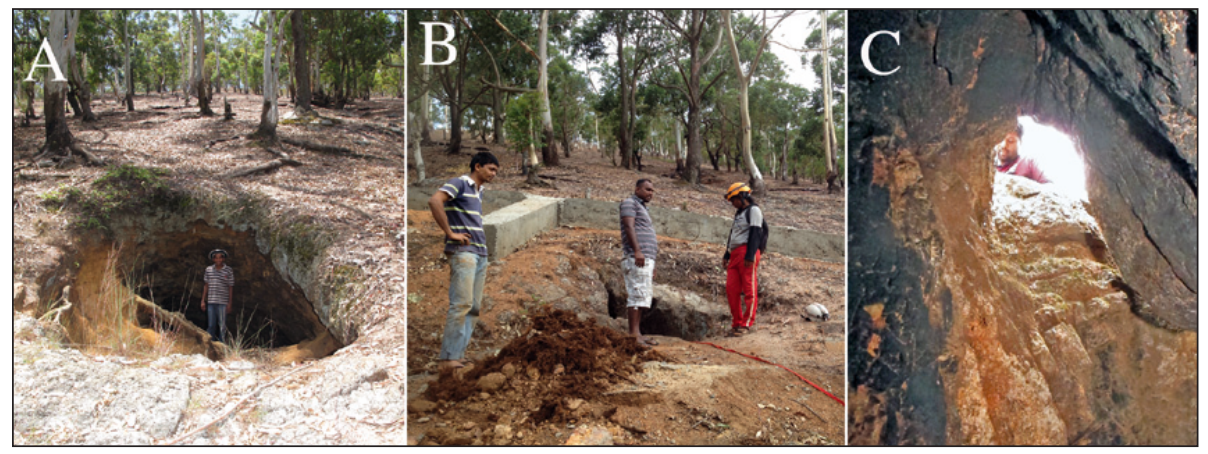

Fig. 5: $A=$ Doline, looking south (Photo: R.A.L. Osborne). B = Blind Entrance. Note concrete wall uphill of entrance (Photo: W.S. Weilange). $C=$ Looking up from inside chamber of Blind Entrance. Note trace of joints dipping to the south in upper right, trace of foliation dipping to the north just below centre field, and head for scale (Photo: R.A.L. Osborne).

\section{CAVE MORPHOLOGY}

In plan (Fig. 2) the cave has its greatest length from south to north, but the most extensive cave development is in the uphill, southern part of the cave. The plan suggests structural guidance by structures striking approximately N-S, E-W and NE-SW.

\section{MAIN ENTRANCE}

The Main Entrance ("C" in Fig. 2) is a vertical elliptical shaft $8.61 \mathrm{~m}$ deep following a joint striking $055^{\circ}$ (Fig. 6A). The shaft intersects small elliptical tubes (Fig. 6B) and sand filled cavities in its eastern face (Fig. 6C). The top $6.65 \mathrm{~m}$ of the shaft are developed in friable quartzite. At $6.65 \mathrm{~m}$ there is a distinct shelf in the shaft formed by two folia of massive dense quartzite. The upper folium is $0.7 \mathrm{~m}$ thick and the lower folium, forming the cave ceiling, is $0.26 \mathrm{~m}$ thick. Below the quartzite the shaft penetrates through $1 \mathrm{~m}$ of saprolite.

There is no breakdown pile at the base of the entrance. This and the morphology of the entrance shaft suggest that the entrance is an exhumed solution or arenization shaft or cupola, not a breakdown feature. The Main Entrance connects to the East Passage.
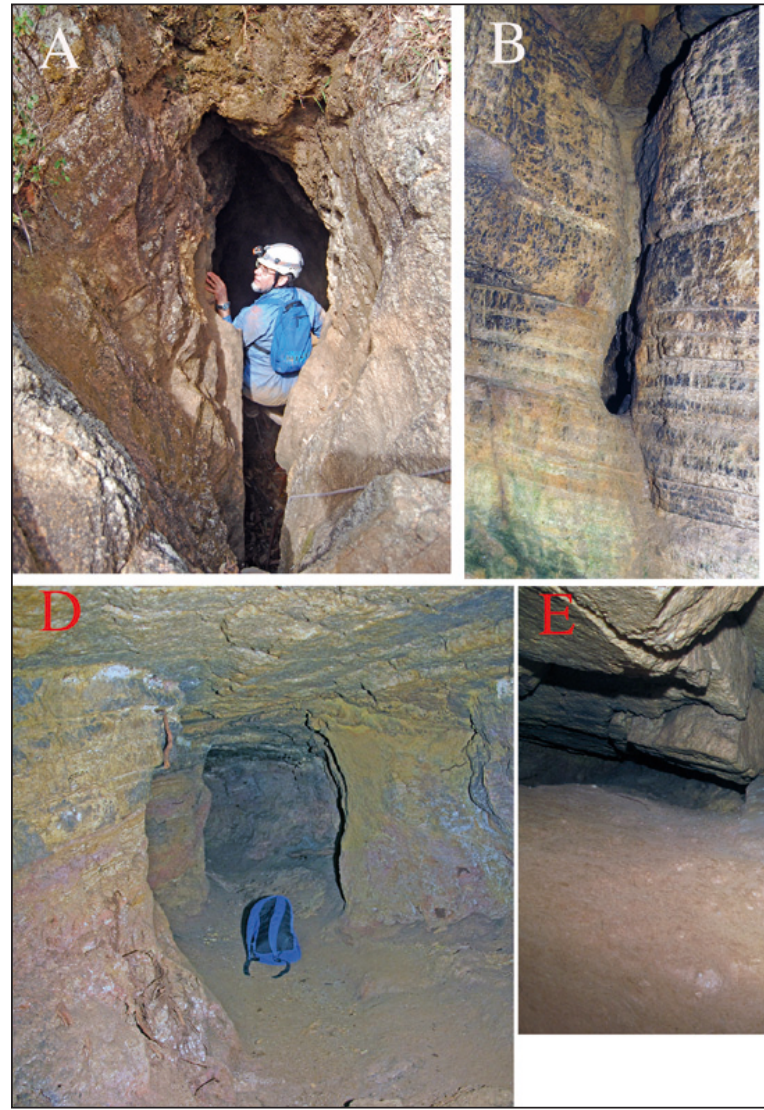
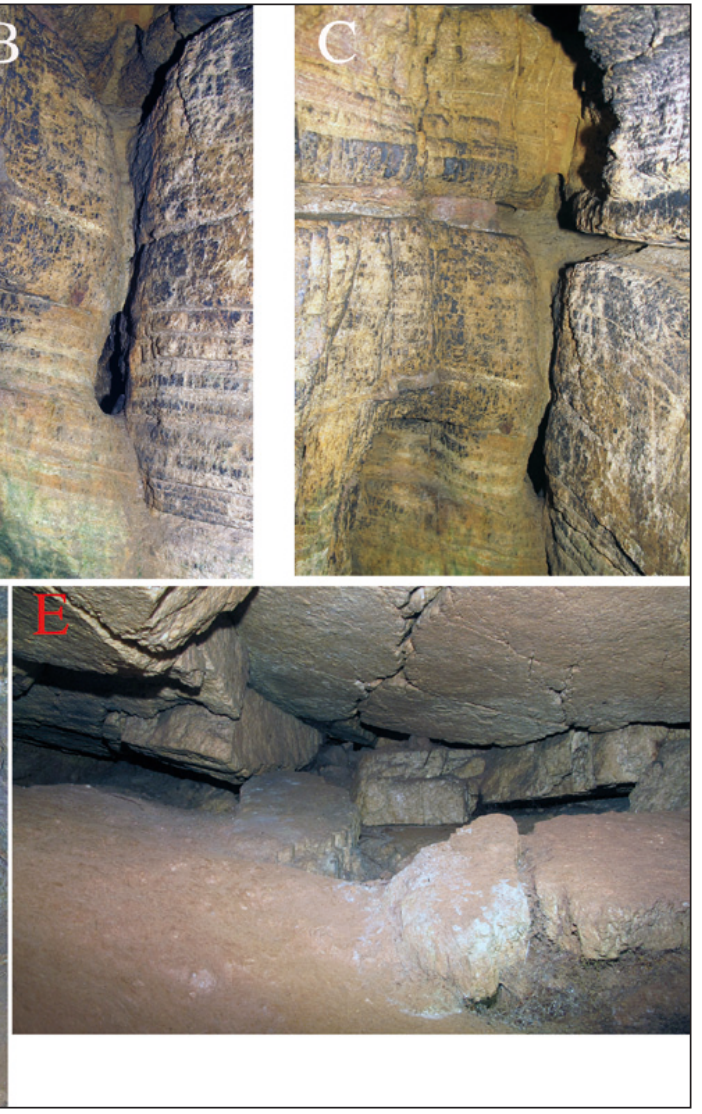

Fig. 6: $A=$ Main Entrance looking down to south (Photo: W.S. Weilange). $B=$ Small elliptical tube intersected by entrance shaft (Photo: R.A.L. Osborne). $C=$ Eastern face of Main Entrance shaft showing joint and sand filled cavities (Photo: R.A.L. Osborne). D = East Passage looking east. Note rectangular passage profile, saprolite floor and quartzite ceiling (Photo: R.A.L. Osborne). $E=$ East Breakdown Chamber. Note breakdown slabs, joint traces in quartzite ceiling and sagging breakdown slabs of quartzite separated from the ceiling (Photo: R.A.L. Osborne). 


\section{EAST PASSAGE}

The East Passage ("D" in Fig. 2) has a mud floor sloping gently to the west. East of the entrance, the passage has a rectangular cross-section approximately $1 \mathrm{~m}$ wide by $1.7 \mathrm{~m}$ high. The walls are vertical and mostly composed of soft, squishy saprolite that can be dug out with a finger, but which still preserves traces of foliation, compositional layering and boudinage. The floor is composed of saprolite, while the ceiling and in some places the upper part of the walls are composed of quartzite (Fig. 6D).
Northwest of the Main Entrance, the East Passage widens and the ceiling lowers as it extends obliquely to connect to the southeastern corner of the Main Passage.

\section{EAST BREAKDOWN CHAMBER}

The East Breakdown Chamber ("E" in Fig. 2) is a small rectangular room approximately $10 \mathrm{~m}$ long $(\mathrm{E}-\mathrm{W})$ by 4 $\mathrm{m}$ wide $(\mathrm{N}-\mathrm{S})$ containing large sagging breakdown slabs of quartzite, which have separated from the ceiling (Fig. $6 \mathrm{E})$.
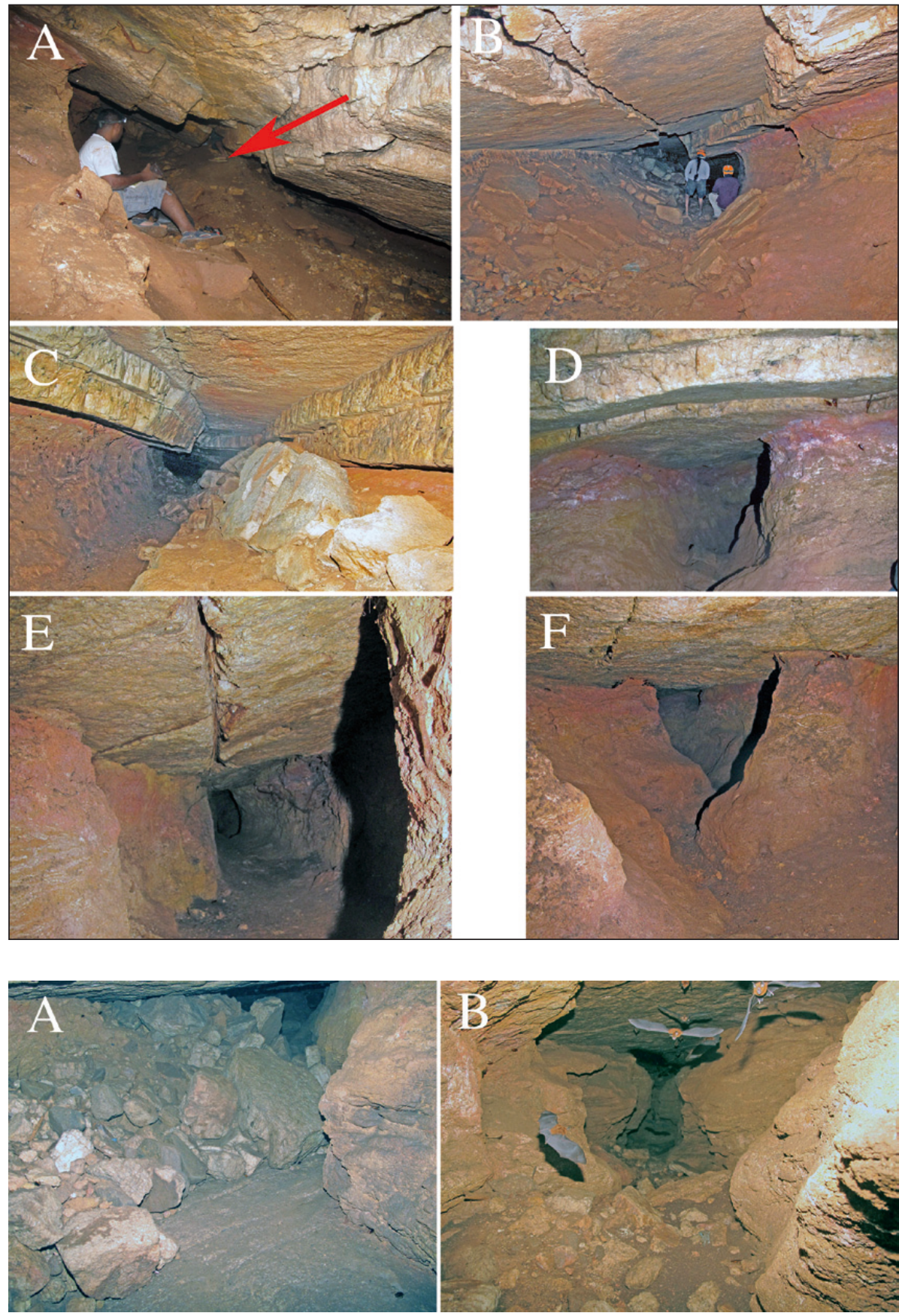

Fig. 7: $A=$ Southern end of Main Passage, looking south. Foot of person entering the West Breakdown Chamber is indicated by red arrow (Photo: R.A.L. Osborne). $B=$ Main Passage looking north. Note guiding joint in ceiling and fallen slabs of quartzite armouring the lower walls (Photo: R.A.L. Osborne). C = Main Passage south. Note slabs of quartzite breakdown on western wall (Photo: R.A.L. Osborne). $D=$ Entrance from Main Passage into Eastern Maze. Note curved folia in quartzite ceiling and incision into the saprolite floor of maze passage (Photo: R.A.L. Osborne). $E=$ Looking east along easterly trending passage in Eastern Maze. Note northerly dip of ceiling and $E-W$ trending guiding joint (Photo: R.A.L. Osborne). $F=$ Looking north along northerly trending passage in Eastern Maze near " $H$ " in Fig. 2. Note meandering canyon in saprolite wall and floor (Photo: R.A.L. Osborne).

Fig. 8: $A=$ Descending Passage, looking up to the SE from " $K$ " in Fig. 2. Note exposed quartzite floor and large quartzite blocks (Photo: R.A.L. Osborne). $B=$ Descending Passage, looking north down irregular section north of " $K$ " in Fig. 2. Note meandering canyon-like walls, floor of rubble with guano and low ceiling height (Photo: R.A.L. Osborne). 


\section{MAIN PASSAGE}

The Main Passage runs almost directly N-S, sloping to the north for $35 \mathrm{~m}$ ("F" in Fig. 2). The passage is $5 \mathrm{~m}$ wide and $1.4 \mathrm{~m}$ high at its southern end (Fig. 7A) and narrows slightly to $4 \mathrm{~m}$ wide and $1.5 \mathrm{~m}$ high at its northern end. The ceiling is formed by the base of a folium of quartzite dipping to the north $\left(20^{\circ} \rightarrow 335^{\circ}\right)$. For most of the passage length an open guiding joint runs down the centre of the cave ceiling (Fig. 7B). The walls are composed of saprolite and at the southern end are almost vertical and parallel giving the passage a rectangular cross-section. For most of the passage length, slabs of quartzite have fallen from the ceiling, armouring the lower walls and giving the passage a U-shaped cross-section (Fig. 7C). The floor in the upper part of the Main Passage is composed of mud derived from the saprolite, but towards the northern, downhill end of the passage, the top of the lower quartzite is exposed in the floor.

\section{WEST BREAKDOWN CHAMBER}

The West Breakdown Chamber is a small chamber west of the southern end of the Main Passage ("G" in Fig. 2). A large fallen slab of quartzite occupies the centre of the chamber.

\section{EASTERN MAZE}

The Eastern Maze is a system of small-scale joint-guided passages located to the east of the Main Passage (" $\mathrm{H}$ " in Fig. 2). The ceilings are mostly composed of quartzite while the walls and floors are mostly composed of saprolite (Fig. 7D). Traces of guiding joints are visible in the ceilings (Fig. 7E). In places small meandering canyons are eroded into the passage floors (Fig. 7F).

\section{DESCENDING PASSAGE}

The Descending Passage ("I" in Fig. 2) is more irregular that the other passages in the cave and descends more steeply than the Main Passage, with the ceiling dipping $25^{\circ} \rightarrow 334^{\circ}$ near the top of the passage and the floor below the first step dipping $25^{\circ} \rightarrow 320^{\circ}$.

The Passage begins with an E-W orientation, (" $\mathrm{J}$ " in Fig. 2) and then turns to descend down-dip to the north. In some places a quartzite floor is exposed below a quantity of large quartzite blocks (Fig. 8A). Towards its northern end the passage becomes a narrow meandering canyon eroded into saprolite (Fig. 8B, "K" in Fig. 2). In this area an E-W trending almost circular tube in saprolite is exposed in the cave wall directly below a south-westerly dipping joint (Dipping $60^{\circ} \rightarrow 233^{\circ}$ ) in the overlying quartzite (Fig. 4B, "L" in Fig. 2). At its northern, downhill end the Descending Passage turns to the east, forming a small chamber ("M" in Fig. 2).

\section{SOUTHWEST PASSAGE}

The Southwest Passage ("N" in Fig. 2) links the two southern parts of the cave. The Passage has a northerly dipping quartzite ceiling and weathered saprolite walls. At its northeastern end sag folds are developed in the quartzite ceiling (Fig. 9A).

The Passage width varies considerably and the composition of the floor changes with quartzite exposed in narrow sections and northerly sloping saprolite floors in wider sections (Fig. 9B). Just east of its junction with the Rising Passage, the Southwest Passage contracts to a V shape in the saprolite below a sloping quartzite ceiling (Fig. 9C). The passage widens again to the west where it appears that a block of saprolite may have slid down on the underlying quartzite and then disintegrated (Fig. 9D). Southwest of its junction with the Rising Passage, the Southwest Passage shrinks dramatically to a small Ushaped tube eroded in the top of the saprolite (Fig. 9E). Traces of guiding joints with a southerly dip are exposed in the ceiling.

On December 2, 2014 a small stream was flowing northeast over rubble along the footwall of the Passage. Further southwest the stream was flowing through a narrow canyon eroded into saprolite in the floor.

\section{RISING PASSAGE}

The Rising Passage ("O" in Fig. 2) connects the Southwest Passage with the Island Room. The Rising Passage has a sloping quartzite ceiling and a floor of saprolite that thins to the northwest (downhill). Near its junction with the Southwest Passage small elliptical pits are developed in the quartzite ceiling (Fig. 10A). The walls of the passage are composed of saprolite. Small anastomosing U-shaped tubes are developed in the top of the saprolite, guided by joints in the overlying quartzite (Fig. 10B). A small watercourse runs along the base of the western wall, leaving a bank of saprolite along the eastern wall. Roughly halfway between the Southwest Passage and the Island Room a residual pillar of saprolite joins the bank to the ceiling (Fig. 4C). Close to its connection with the Island Room the Rising Passage turns to the west, resulting in the cave floor and ceiling dipping towards the northwest (Fig. 10C).

\section{ISLAND ROOM}

The Island Room ("P" in Fig. 2) is a diamond-shaped chamber with a N-S principal axis with a diamondshaped "island", a remnant of saprolite occupying the centre of the room. To the northwest of the "island" a canyon is incised into the saprolite floor of the room (Fig. 11A). The western face of the "island" provides a good section through the saprolite (Fig. 11B), seen in detail in Fig. 4D. Irregular hollows guided by jointing penetrate 
into the quartzite ceiling of the Island Room. The largest hollow is an elliptical pocket with a long axis of $1 \mathrm{~m}$ and a short axis of $0.5 \mathrm{~mm}$, guided by a NE-SW striking joint. This elliptical pocket penetrates for $1 \mathrm{~m}$ into the cave ceiling (Fig. 11C).

\section{CUPOLA}

A cupola is developed in friable and saccharoidal quartzite above the ceiling quartzite at the southwestern end of the Island Room ("Q" in Fig. 2). The cupola has a prin- cipal axis of $3.8 \mathrm{~m}$, guided by a joint striking $030^{\circ}$ and a minor axis of $2 \mathrm{~m}$, perpendicular to the long axis. The guiding joint and foliation in the quartzite can be seen in the wall at the northeastern end of the cupola (Fig. 11D). The highest point of the cupola is at the southwestern end where it rises $3.8 \mathrm{~m}$ above the cave floor (Fig. 11E). A boulder blocks the aperture at the highest point. There is a great quantity of fine sand on the cave floor below and in the vicinity of the cupola.
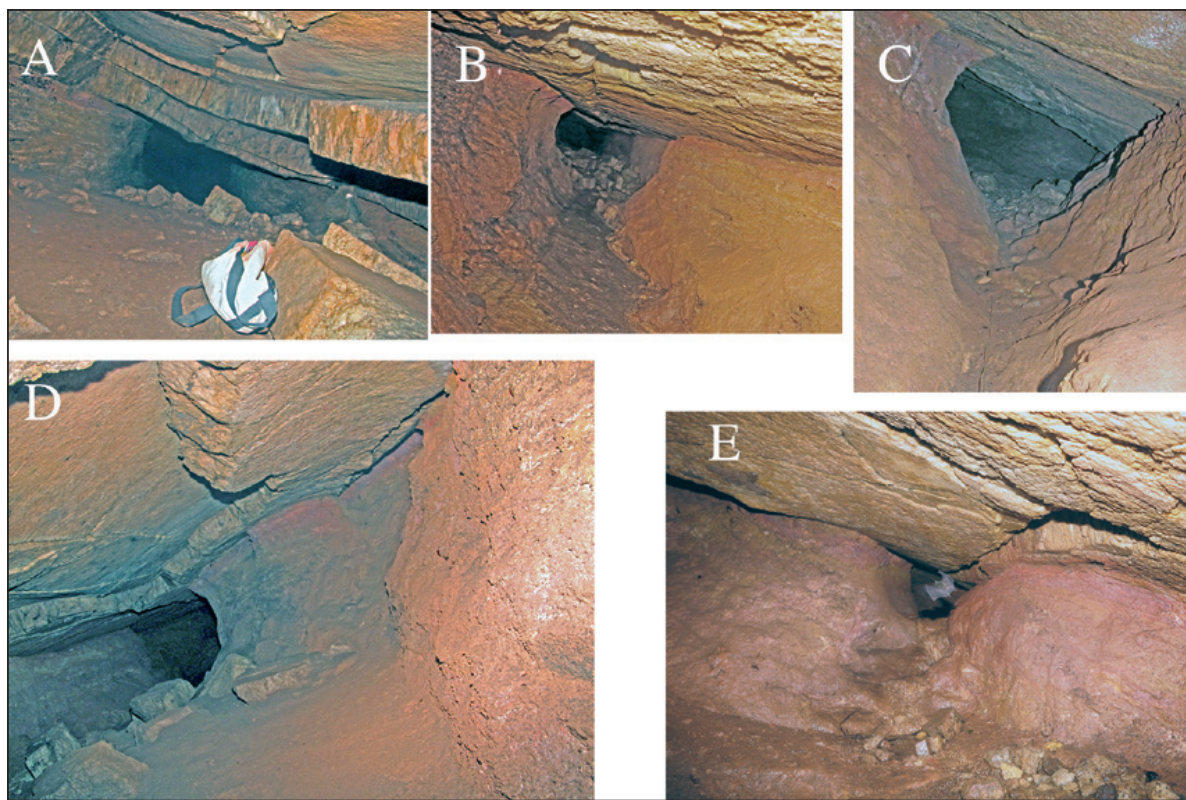

Fig. 9: $A=$ Looking southwest into the Southwest Passage adjacent to its junction with the Main Passage. Note distinct sag fold in quartzite ceiling (Photo: R.A.L. Osborne). $B=$ Looking southwest. Note dipping ceiling and floor with remnant of saprolite forming lower footwall (Photo: R.A.L. Osborne). $C=V$-shaped section of Southwest Passage close to junction with Rising Passage. Note quartzite ceiling dipping to the north with saprolite forming floor, headwall and footwall (Photo: R.A.L. Osborne). D = Looking northeast from junction of Southwest Passage with Rising Passage showing space from which a block of saprolite may have slid. $E=$ Termination of Southwest Passage. Note tube in top of saprolite guided by joint in overlying quartzite (Photo: R.A.L. Osborne).

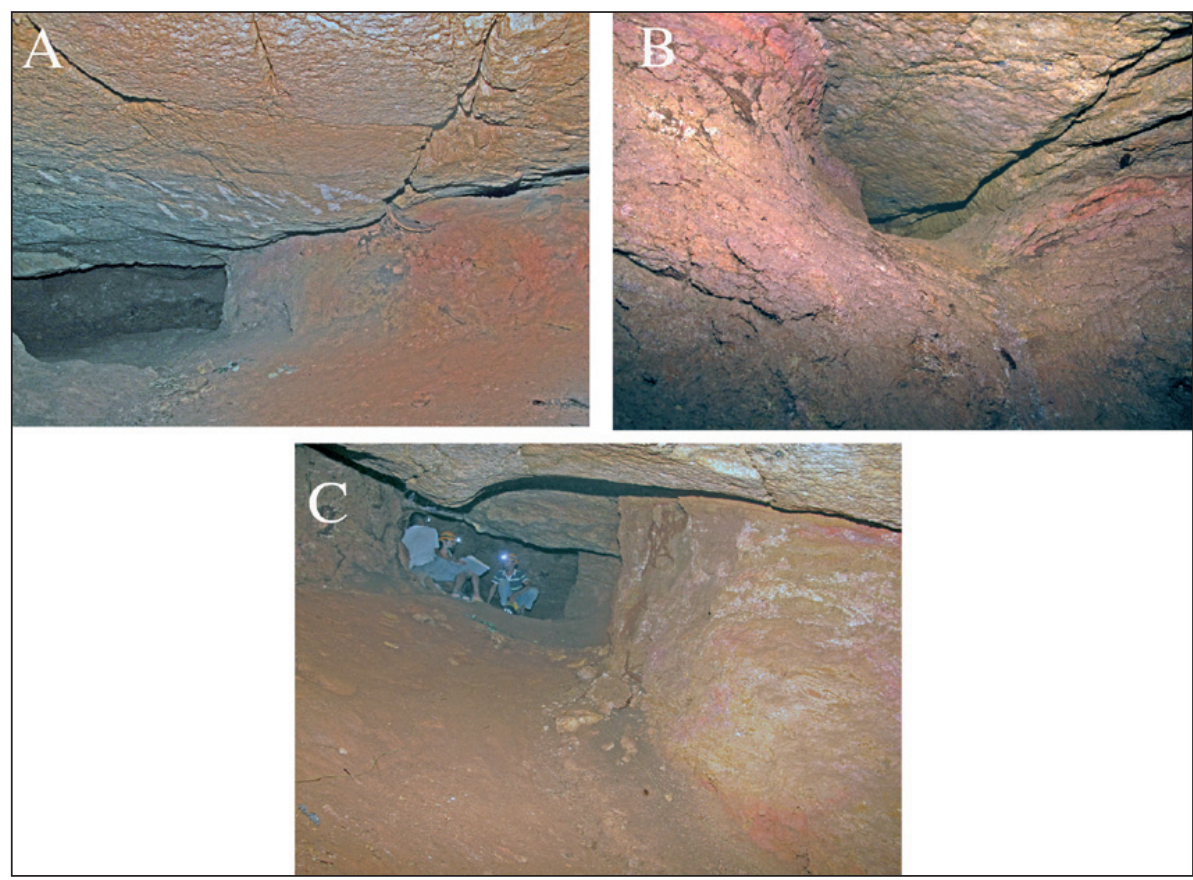

Fig. 10: $A=$ Looking down the Rising Passage towards the connection with the Southwest Passage. Note small elliptical pits and traces of joints in quartzite ceiling (Photo: R.A.L. Osborne). B = Tube in saprolite directly below quartzite and following a joint in the southwestern wall of the Rising Passage (Photo: R.A.L. Osborne). C = Looking up Rising Passage towards Island Room. Note floor and ceiling dipping to the northwest, incision close to wall in northwestern (right) side of passage and people for scale (Photo: R.A.L. Osborne). 


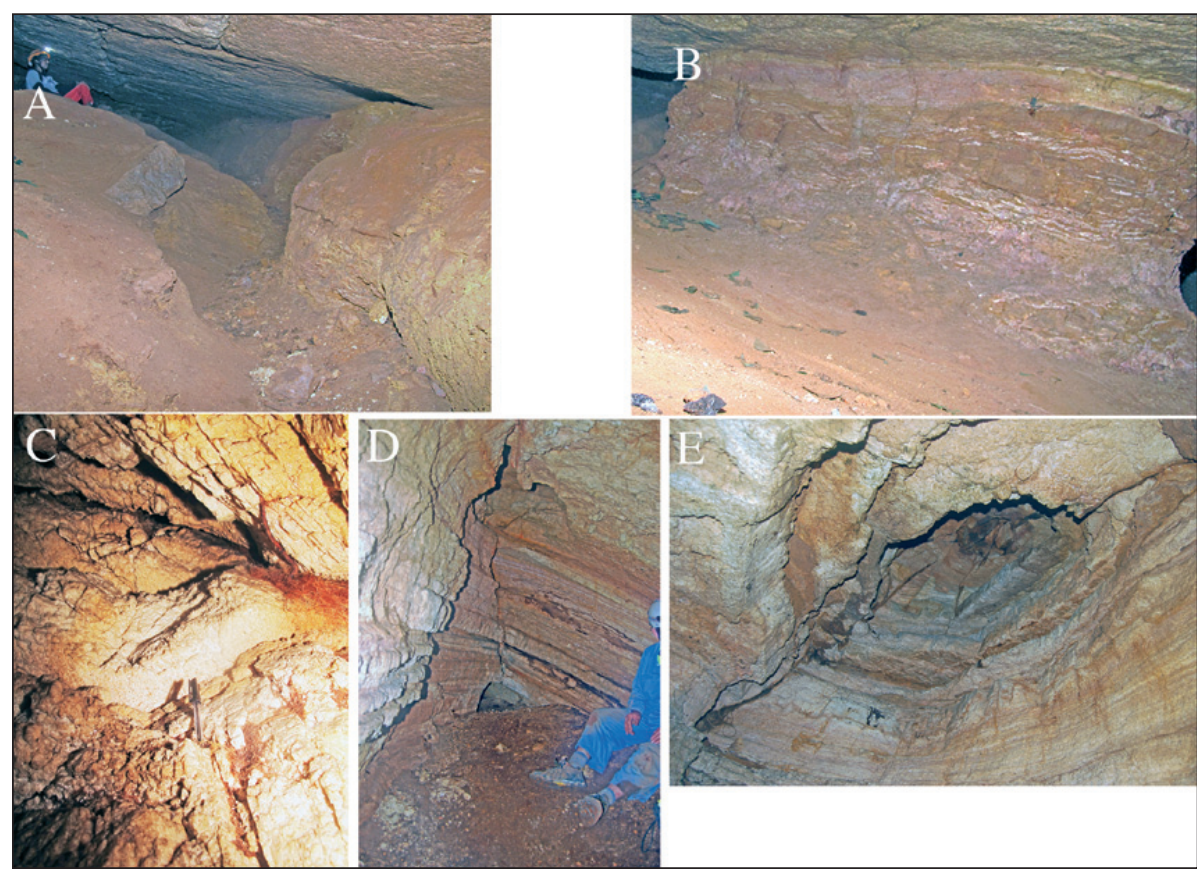

Fig. 11: $A$ = Looking up to Island Room from Rising Passage. Note canyon and bank of saprolite on right hand (northwestern) side and figure on upper left for scale (Photo: R.A.L. Osborne). $B=$ Looking south showing side of the "island" exposing section through saprolite (Photo: R.A.L. Osborne). $C=$ Elliptical pocket in the ceiling of the Island Room penetrating into the ceiling quartzite. Pen for scale is $130 \mathrm{~mm}$ (Photo: R.A.L. Osborne). $D=$ Looking towards floor at northeastern end of $\mathrm{cu}$ pola. Note trace of guiding joint in midfield and foliation in quartzite dipping to the north (Photo: W.S. Weilange). $E=$ Looking up into highest point of cupola at southwestern end. Note trace of guiding joint and boulder at highest point (Photo: W.S. Weilange).

\section{SPELEOGENESIS}

Two different cave development processes can be identified in the rock mass containing Sthreepura Cave. One process, arenization, is limited to the rock mass between the ceiling quartzite and the surface. The other process, selective removal of saprolite, is occurring between the floor and ceiling quartzites.

The Main Entrance shaft intersects small elliptical tubes in the quartzite (Fig. 6B). These tubes extend to the south on a bearing of $210^{\circ}$. The Cupola, aligned to the same bearing as the tubes, is entirely developed in saccharoidal and friable quartzite above the top of the ceiling quartzite and is connected to the underlying cave by localised failure of the ceiling quartzite. Sand similar to that in the vicinity of the Cupola fills open joints in the eastern face of the Main Entrance shaft (Fig. 6C).

The presence of loose sand at the base of the $\mathrm{Cu}$ pola and of sand filled cavities in the Main Entrance shaft suggests that open cavities in the saccharoidal and friable quartzite such as the Main Entrance, Cupola and the chamber below the Blind Entrance formed by arenization of the quartzite along joints, followed by the resulting sand being washed into and through the underlying cave developed in the saprolite. This implies that the arenization of the upper quartzites and the weathering of the underlying saprolite need not have occurred at the same time. Spaces in the saccharoidal and friable quartzites, however, could only have been opened after the lower level of the cave formed.
The tube below the quartzite in the Descending Passage (Fig. 4B), the termination of the Southwest Passage (Fig. 9E) and the tubes in the wall of the Rising Passage (Fig. 10B) all suggest that cave development in the saprolite began with water movement along joints being concentrated at the boundary between the ceiling quartzite and the saprolite, probably under phreatic conditions.

The next step in cave development was headward erosion following the lowering of the water table. This process is beginning to occur at the termination of the Southwest Passage and is at a later stage of development in the canyon in the Eastern Maze (Fig. 7F).

As channels in the saprolite widened the ceiling quartzite failed along the guiding joints resulting in slab breakdown. In some localities this resulted in the formation of breakdown chambers. In the northern section of the Main Passage the fallen slabs armoured the passage walls preventing undercutting and subsequent failure.

Apart from piles of quartzite blocks and a small amount of guano slime with mica flakes there is little clastic sediment in the cave. This lack of sediment is puzzling, given the evidence on the surrounding land surface of significant denudation. It is possible that the cave entrances were not open when the denudation occurred. Since the earliest reference to the cave in the cave bibliography of Gebauer (2010) dates from the 1970s, it is possible that the cave entrances opened as a consequence of and following anthropogenic denudation. 


\section{DISCUSSION}

In most caves described as being formed by phantom rock or arenization processes, the cave walls, floor and ceilings are composed of unaltered or relatively unaltered bedrock. Caves formed by these processes begin by alteration of bedrock along joints, followed by removal of the altered rock leaving behind caves with walls and ceilings of unaltered rock. In these caves, the shape of the alteration or weathering front determines the shape of the cave (Dubois et al. 2014; Wray \& Sauro 2017).

In the case of Sthreepura Cave at Kiriwanagama, excavation of the upper level follows the normal style of phantom rock and arenization speleogenesis. However while the lower level of the cave has unaltered bedrock floors and ceilings, the walls are entirely composed of saprolite. Drill soundings and observations in the cave suggest that there is not a confining wall or zone of unweathered bedrock close to or behind the saprolite walls of the cave.

The lower level of Sthreepura Cave at Kiriwanagama is not a phantom rock or arenization cave in the normal sense of the term, as the walls of the lower level are composed of saprolite not unweathered bedrock. It is also not a soil pipe as the saprolite lacks soil horizons and other soil-like features and the cave was not formed by any of the processes recognised by Pierson (1983). Unlike soil pipes the main lower level of the cave did not form on top of an aquiclude but in saprolite below an overlying aquiclude. Sthreepura Cave at Kiriwanagama appears to be in a class of it own: a network cave in saprolite, related to, but not the same as phantom rock or arenization caves.

Network caves in saprolite are uncommon and probably short-lived phenomena but may play an important role in large-scale cave development in granitic rocks in Sri Lanka and elsewhere. Sri Lankan arch caves in gneiss described by Osborne et al. (2013) appear to have formed by the removal of large volumes of phantom rock. An archaeological excavation in the floor of Fa-Hein Lena, a large gneiss arch cave, penetrates through $6 \mathrm{~m}$ of phan- tom rock. The bottom of the excavation intersects tubes with a circular cross-section developed entirely in phantom rock. The tubes exposed in the excavation are located in the centre of the cave approximately $14 \mathrm{~m}$ from both bedrock walls. So, like the passages in Sthreepura Cave at Kiriwanagama these tubes are caves in weathered rock, and have weathered rock walls remote from the unweathered bedrock. Osborne et al. (2013) also described, Foliation Plane Cave at Karannagoda Rajamaha Viharaya near Ratnapura formed by the removal of a large volume of phantom rock from between two resistant folia. Holes in an isolated thin sheet of phantom rock in the cave suggest that a system of caves was developed in the mass of phantom rock before the phantom rock was almost completely removed.

In both these cases it appears that caves were developed in the weathered rock before the almost complete removal of the weathered (phantom) rock from between the unweathered bedrock walls, floor and ceiling of the final cave. This suggests that the cave forming mechanism in the lower level of Sthreepura Cave at Kiriwanagama may be the mechanism for early-stage removal of phantom rock from large gneiss caves in Sri Lanka.

Osborne et al. (2013) commented that the cave forming processes and the morphology of Sri Lankan gneiss breakdown caves mimicked those of conventional karst caves. We can see similar mimicking in the lower level of Sthreepura Cave at Kiriwanagama. The formation of joint-guided circular tubes under phreatic conditions, followed by incision after vadose conditions were established, mimics the classic sequence of karst cave development recognised by Bretz (1942). Sthreepura Cave at Kiriwanagama also has similarities with interstratal karst caves. If it were formed in a layer of soluble rock, Sthreepura Cave at Kiriwanagama could be considered an example of a "sandwiched, 2D network cave" as described by White (1988).

\section{CONCLUSIONS}

Most of Sthreepura Cave at Kiriwanagama is a network cave in saprolite, not an arenization or phantom rock cave. While the upper level of the cave is a product of the arenization of quartzite, the lower level of the cave is developed in a layer of saprolite. Speleogenesis in the lower level began with the formation of tubes with a circular cross-section in the saprolite. The tubes are located directly below and follow joints in the quartzite cave ceiling. The tubes probably developed under phreatic conditions. After the establishment of vadose conditions, water flowed through the tubes, cut down into the saprolite forming canyons and then locally removed the saprolite to form a network of passages with a rectangular crosssection. Undercutting of the cave walls resulted in cata- 
strophic breakdown forming breakdown chambers, suggesting that these caves could be short-lived phenomena. The Main Passage has avoided significant failure because fallen slabs of quartzite have armoured the lower cave walls, inhibiting undercutting.

\section{ACKNOWLEDGEMENTS}

The authors would like to acknowledge the assistance of Dr W.S. Weliange for leading and providing transport for the initial field trips to Sthreepura Cave at Kiriwanagama; A.S. Dandeniya and the LICAS mapping team; P. Algiriya, S. Senanayake and M. Champika for their hard work and attention to detail in producing the cave map and other LICAS cavers; N. Prasannajitjh and A. Weliange who assisted with the fieldwork. Professor Adikari, former Director General of the Central Cultural Fund is thanked for providing transport for some of the fieldwork. A/Prof Osborne would particularly like to thank Mrs Aruni Premathilake and family for accommodation and sustenance, and Ayoma Weliange for his assistance with transport and logistics in Sri Lanka. Ms Penney Osborne assisted by proofreading the drafts. Ross Pogson publishes with the permission of the Trustees of the Australian Museum. Where not otherwise acknowledged, images are by the authors.

\section{REFERENCES}

Aubrecht, R., Lánczos, T., Gregor, M., Schlögl, J., Šmída, B., Liščák, P., Brewer-Carías, Ch. \& L. Vlček, 2011: Sandstone caves on Venezuelan tepuis: Return to pseudokarst? -Geomorphology, 132, 3-4, 351-365.DOI: https://doi.org/10.1016/j.geomorph.2011.05.023

Aubrecht, R., Lánczos, T., Gregor, M., Schlögl, J., Šmída, B., Liščák, P., Ch. Brewer-Carías, Ch. \& L. Vlček, 2013: Reply to the comment on sandstone caves on Venezuelan tepuis: Return to pseudokarst? -Geomorphology, 179, 2013, 179-203. DOI: https://doi.org/10.1016/j.geomorph.2012.11.015

Basnayake, V., 1983: Carbon dioxide concentration in the atmosphere of Isthripura Cavern, Central Province, Sri Lanka. -Journal of the National Science Council of Sri Lanka, 11, 1, 51-55.

Bowden, D.J., 1980: Sub-laterite cave systems and other pseudo-karst phenomena in the humid tropics: The example of the Kasewe Hills Sierra Leone. -Zeitschrift für Geomorphologie, N.F. 24,1, 77-90.

Braga, M.S., Paquet, H. \& A. Begonha, 2002: Weathering of granites in a temperate climate (NW Portugal): granitic saprolites and arenization. - Catena, 49, 1, 41-56. DOI: https://doi.org/10.1016/S03418162(02)00017-6

Bretz, J.H., 1942: Vadose and phreatic features of limestone caverns. -Journal of Geology, 50, 675-811.

Cooray, P.G., 1994: The Precambrian of Sri Lanka: a historical review. -Precambrian Research, 66, 1-4, 3-18.
Dandeniya, A.S., Algiriya, A.K.P.P., Senanayake, S. \& M. Champika, 2015: Plan of the Sthreepura Tunnels. -Welimada, Lanka Institute of Cave Science, unpubl.

Dubois, C.Y., Quinif, Y., Baele, J-M., Barriquand, L., Bini, A., Bruxelles, L., Dandurand, G., Havron, C., Kaufmann, O., Lans, B., Maire, R., Martin, J., Rodet, J., Rowberry, M.D., Tognini, P. \& A. Vergari, 2014: The process of ghost-rock karstification and its role in the formation of cave systems.- Earth-Science Reviews, 131, 116-148. DOI: https://doi.org/10.1016/j. earscirev.2014.01.006

Gebauer, H.D., 2010: Resources on the speleology of Sri Lanka.- [Online] Available from: http://www. speleologie.de/forschung/lk/general/resources/ bhb_2010_lk.pdf/ [Accessed 5 th June 2018]

Geršl, M., Stepišnik, U. \& S. Šušteršič, 1999: The "unroofed cave" near the bunker (Laški Ravnik).- Acta Carsologica, 28, 2-3, 77-90.

Häuselmann, P. \& P. Tognini, 2005: Kaltbach Cave (Siebenhengste, Switzerland): phantom of the sandstone? - Acta Carsologica, 34, 2, 383-396. DOI: https://doi.org/10.3986/ac.v34i2.265

Kale, V.S., 2014: The laterite-capped Panchgani Tableland, Deccan Traps.- In Kale V.S. (ed.) Landscapes and Landforms of India. Springer, pp. 217-222. [Online] Available from: http://link.springer.com/ chapter/10.1007/978-94-017-8029-2_23 [Accessed $5^{\text {th }}$ June, 2018] 
Martini, J.E.J., 1979: Karst in Black Reef Quartzite near Kaapsehoop, Eastern Transvaal.- Annals of the South African Geological Survey, 13, 115-128.

McFarlane, M. J. \& C.R. Twidale, 1987: Karstic features associated with tropical weathering profiles.- Zeitschrift für Geomorphologie, Suppl. Bd, 64, 73-95.

Osborne, R.A.L., Weliange, W.S., Jayasingha, P., Dandeniya, A.S., Algiriya, A.K.P.P. \& R.E. Pogson, 2013: Caves and karst-like features in Proterozoic gneiss and Cambrian granite, southern and central Sri Lanka: an introduction.- Acta Carsologica, 42, 1, 25-48. DOI: https://doi.org/10.3986/ac.v42i1.630

Pierson, T.C., 1983: Soil pipes and slope stability.- Quarterly Journal of Engineering Geology, London, 16, 1-11.

Quinif, Y., 2011: Ghost-rock structures and the nature of Azé Caves.- Quaternaire, Hors-série, 4, 7-14.

Retallack, G.J., 2010: Lateritization and bauxitization events.- Economic Geology, 105, 655-667. DOI: https://doi.org/10.2113/gsecongeo.105.3.655

Sauro, F., Lundberg, J., De Waele, J. Tisato, N. \& E. Galli, 2013: Speleogenesis and speleothems of the Guacamaya Cave, Auyan Tepui, Venezuela. In: M. Filippi \& P. Bosak (eds.), 16th International Congress of Speleology, Czech Republic, Brno, July 21-28, 2013, Proceedings Volume 3, 298-304.
Šušteršič, F., 2003: Collapse dolines, deflector faults and collector channels.- Speleogenesis and evolution of karst aquifers, 1, 3, 1-10.

Twidale, C.R., 1987: Sinkholes (dolines) in lateritised sediments, western Sturt Plateau, Northern Territory, Australia.- Geomorphology, 1, 33-52.

Urban, J., Ciborowski, T., Paternoga, R., Hercman, H. \& G. Sujka, 2007: The genetical types of caves in the Polish Lowlands.- Nature Conservation, 63, 85-94.

Vergari, A \& Y. Quinif, 1997: Les paleokarsts du Hainaut (Belgique).- Geodinamica Acta, 10, 4, 175-187.

White, W.B., 1988: Geomorphology and hydrology of karst terrains.- Oxford University Press, 464 pp., Oxford.

Wray, R.A.L. \& F. Sauro, 2017: An updated global review of solutional weathering processes and forms in quartz sandstones and quartzites.- Earth-Science Reviews, 171, 520-557. DOI: https://doi.org/10.1016/j.earscirev.2017.06.008 